\title{
ONLINE SOIL MOISTURE AND MICROCLIMATE INVESTIGATIONS ON AGROFORESTRY AND AgRICULTURAL FIELD Plots
}

\author{
Katalin SoMfALVI-TóTH, Zoltán BURUCS, Boglárka NYISZTOR
}

Kaposvár University, Faculty of Agricultural and Environmental Sciences

H-7400 Kaposvar Guba S.u. 40.

\begin{abstract}
Agroforestry is a traditional cultivation method, which can bridge the gap between nature conservation and agriculture systems. Hungary is one of the most vulnerable countries in the term of climate change, and according to climatological forecasts, several areas in the Carpathian basin will be exposed to extensive and prolonged droughts in the next decades. Agroforestry can moderate the negative effects of the projected changes. The regional share of this new concept should be increased, but first science has to demonstrate its clear benefits. So using online measurement technologies microclimate and soil moisture changes can be detected with high temporal and spatial distribution for longer periods in order to obtain information on the smallest deviations of microclimatic elements that could not be detected in conventional ways. In our study a 1 ha completely wind shielded agroforestry plot and a nearby situated natural wind-running field were investigated, using 1-1 automatic weather station as well as $5+1$ of $90 \mathrm{~cm}$ soil probes, which were used to measure the changes of soil moisture among $10 \mathrm{~cm}$ layers. We examined the climatological response to the forest belt compared to the open, traditional field ("control area") based on the following parameters: 10 meter wind speed, 10 meter wind direction, $2 m$ temperature, relative bumidity, the amount and intensity of rainfall, the amount and duration of dew formation, the volume\% of soil moisture.
\end{abstract}

Keywords: agroforestry, microclimate, soil moisture, climate change

\section{INTRODUCTION}

Nowadays agriculture has to face a lot of challenges, like nourishing the growing population or the negative effects of climate change. One possible solution could be achieving higher yields or increasing the rate of agroforestry in less favourable plots. By definition, this is a form of land usage, where combinations of different branches of agriculture alongside elements of forestry materialize at the same time, the members of this system interact, which creates ecological and economic benefits (Gyuricza and Borovics, 2018). Local climate factors can be improved by applying systems of agroforestry in the area (Vityi et al., 2014). Due to the reduced wind speed, the lower radiation, and the higher relative humidity, the atmospheric drought can be reduced. Also, free-range animals and different kinds of crops can benefit from the shade. Also, the falling fruits and leaves can supplement the food supplies of livestock and wildlife, who can find also refuge in the forest belt (Keserü et al., 2015). Agroforestry contributes to biodiversity, maintains protection against deflation and erosion, improves water quality and carbon sequestration. Subsequently, by cutting down the trees we can expect additional revenue (Nair and Garrity, 2012). One of the 
benefits of this environmentally friendly production method is being less vulnerable to market conditions, it can create a link between agriculture personnel, hunting associations and beekeepers, while it enriches the diversity of the countryside. With varied planting of tree species with different flowering times it can be used as a bee pasture to provide nourishment for the bees throughout the whole growing season (Keserü et al., 2014). This system's productivity exceeds the production of equivalent plots of solely arable crops or forestry.

\section{MATERIALS AND METHODS}

Our investigations were carried out in two areas around Földes in Hajdú-Bihar County. One is a closed agroforestry plot and the other one is an open, traditionally cultivated field ("control area") in $5 \mathrm{~km}$ apart. In the agroforestry experimental area there are 3 soil probes in the crop field (grain in the time of the investigation), 2 soil probes in the forest belt and 1 automatic meteorological station in the geometric center of the area. There is a meteorological station and a soil probe on the control area. Both BOREAS meteorological stations were installed in March 2018. 10meter wind speed (m/s), 10meter wind direction (degrees), $2 \mathrm{~m}$ temperature $\left({ }^{\circ} \mathrm{C}\right)$, relative humidity $(\%)$, the amount $(\mathrm{mm})$ and intensity $(\mathrm{mm} / \mathrm{h})$ of rainfall, the amount $(\%)$ and duration $(\mathrm{s})$ of dew formation are recorded with 10-minute resolution. SENTEK soil probes measure the volume of soil moisture $\left(\mathrm{V}_{\mathrm{TF}} \%\right)$ and soil temperature $\left({ }^{\circ} \mathrm{C}\right)$ from 5 to $85 \mathrm{~cm}$ up to a depth of $10 \mathrm{~cm}$ with 60-minute time resolution. The measurements were started on April 20, 2018. The hourly differences of $2 \mathrm{~m}$ temperature, relative humidity were calculated. The sample size was at least 180 in every hour of the day in each month, which made proper statistical calculations possible. Besides, the comparison of evapotranspiration, soil moisture and wind speed are presented. To visualize the changes of soil moisture along the depth of $85 \mathrm{~cm}$ in 2D flow charts, linear interpolation was applied to increase the spatial resolution from $10 \mathrm{~cm}$ to $1 \mathrm{~cm}$. We assumed that the change of soil moisture was linear between two measurement points $(5,15, \ldots 85 \mathrm{~cm})$. All the figures were created with $\mathrm{R}$ free statistical software ( $R$ core team, 2017)

The goal of the research is to highlight the differences and similarities of agroforestry and open field crop production from the perspective of soil water management and microclimate properties. By analyzing and comparing the received results we can determine the effects of agroforestry on the crop production.

\section{RESULTS AND DISCUSSION}

\section{Comparison of temperature, humidity and evapotranspiration}

As a first step, the daily means of temperature, relative humidity and evaporation were calculated, but it was too robust to highlight the fine differences in the microclimate. After the visualization of the temperature in 10-minute resolution, systematic deviation can be assumed in similar times of the day (Figure 1), so the hourly differences of temperature and relative humidity were calculated (Figure 2 and Figure 3). Zero line shows when the temperature and relative humidity is equal in both areas. The values are positive, when the temperature/relative humidity is higher in 
the control area, and inversely, the negative values refer to the condition when the temperature/relative humidity is higher on the agroforestry plot.

Figure 1

Daily range of temperature on the agroforestry plot and the control plot between 1-5 July 2018

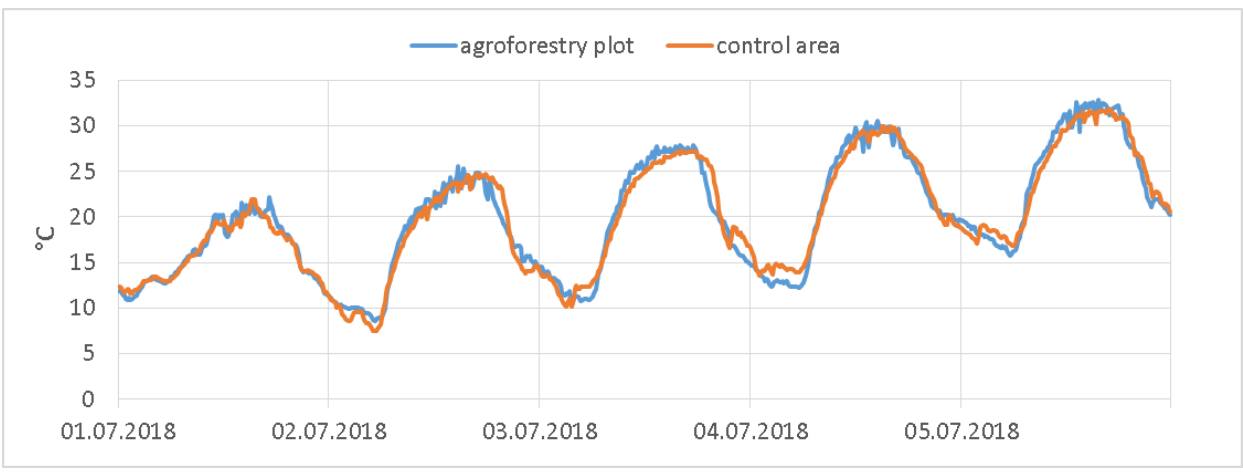

Figure 2

Hourly temperature differences

between the control plot and the agroforestry plot

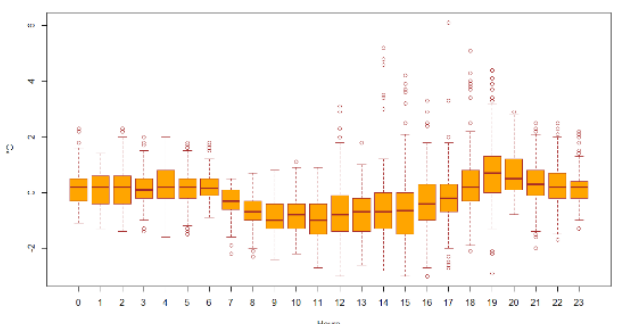

July 2018

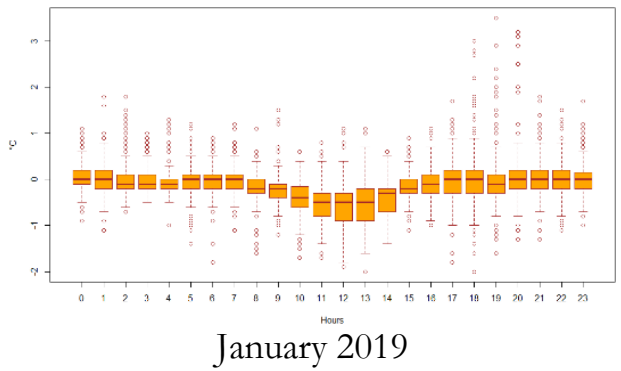

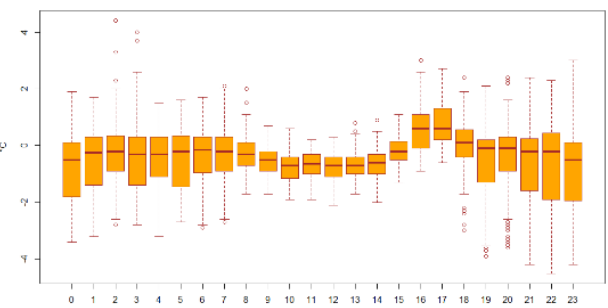

October 2018

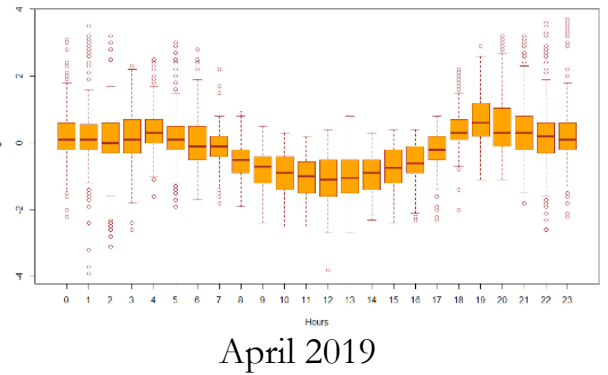

In July 2018 the average temperature of the control area was a few tenths of a degree hotter at night and dawn compared to the agroforestry plot. However, from 
dawn to late afternoon, the agroforestry area had higher temperatures compared to the control area. This can be explained by the fact that the wind speed in the agroforestry plot was significantly lower and as a consequence, the atmospheric mixing could not exert its effect, therefore the atmospheric energetics (radiation and irradiation) governed the degree of temperature rise and cooling in the agroforestry plot. As a result, the temperature rose after dawn and dropped after twilight at a higher rate (Figure 2 upper left). In October, in late afternoon, the shade effect of the forest could be detected due to the lower angle of incidence, so the temperature decreased faster on the agroforestry plot (Figure 2 upper right). In winter (Figure 2 bottom left), in the absence of deciduous leaves, the temperature values in the two areas were almost completely equalized.

The atmosphere is a dynamic system, so temperature and humidity are closely related. The warmer the air is, the more water vapour can be absorbed proportionally per unit volume. As a result, the area with higher daily temperature fluctuations showed higher daily fluctuations of relative humidity as well (Figure 3).

\section{Figure 3}

\section{Hourly differences of relative humidity between the control plot and agroforestry plot}

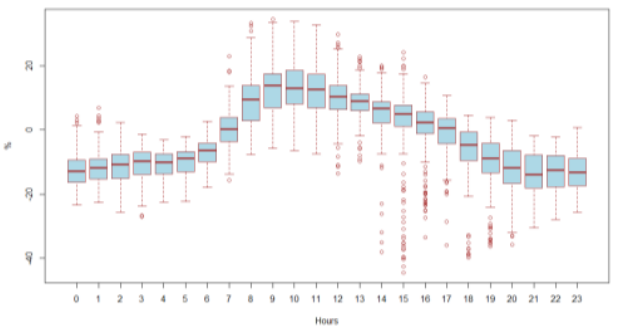

July 2018

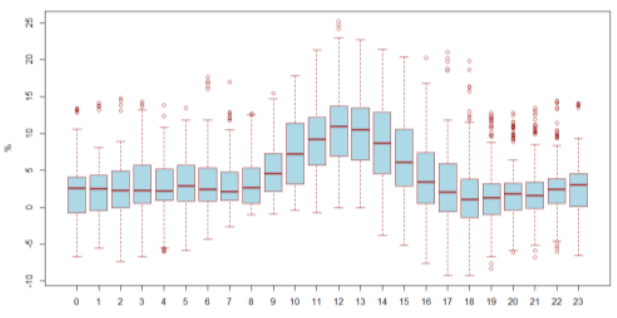

Hans

January 2019

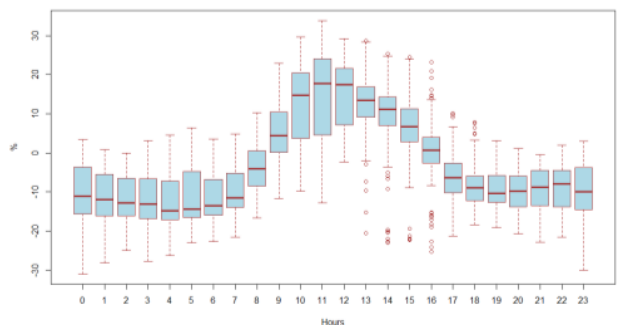

October 2018

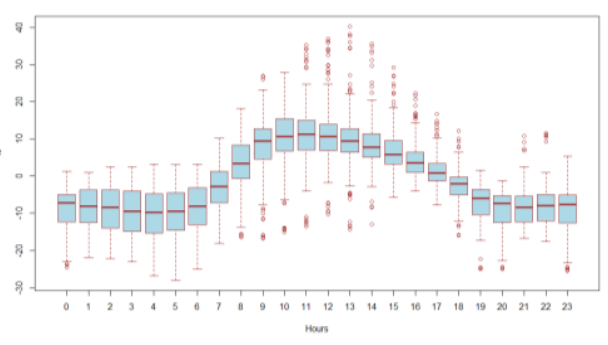

April 2019

At night and dawn, when the temperature on the control area was higher, the relative humidity of the air was lower. During the day, a reversed trend could be observed. In this case, the forest surrounded area had a higher temperature, and at the same time had lower relative humidity. However, this did not mean lower absolute water content in the air, because relative humidity strongly depends on the 
air temperature. Using statistical t-probe it can be stated that there were significant differences in relative humidity in July and October 2018, and in April 2019. In winter there was no significant effect of the forest belt around the agroforestry plot.

Evaporation rate strongly depends on temperature, relative humidity and wind speed. Higher temperatures and higher wind speeds increase the evaporation, while high humidity prevents more intensive evaporation. The average wind speed in the agroforestry plot was lower due to the effect of the wind shade and the temperature was higher than the control area's value, especially at noon in summer. Potential daily evapotranspiration in July 2018 was lower in the agroforestry plot than in the control area (Figure 4). Evaporation of green vegetation ensured higher water vapor content, and due to the area being closed, it was easily retained. These differences were more determined in the area of high pressure systems (anticyclone), when there was no mixing effect in the lower atmosphere owing to the low wind speeds. On the contrary, on $25^{\text {th }}$ July 2018 a cold front passed over the area causing higher wind speeds, and the rate of evaporation equalized on the experimental areas. In October, evaporation was more balanced, which can be explained by the leaf fall and the cooler weather. However, in January there was a significant difference in the values of potential evapotranspiration, as evaporation in the agroforestry plot was significantly higher than in the control area. This can be explained by the higher moisture content of the soil.

\section{Figure 4}

\section{Daily value of potential evapotranspiration ( $\mathrm{mm})$ on agroforestry and the control plot in July 2018}

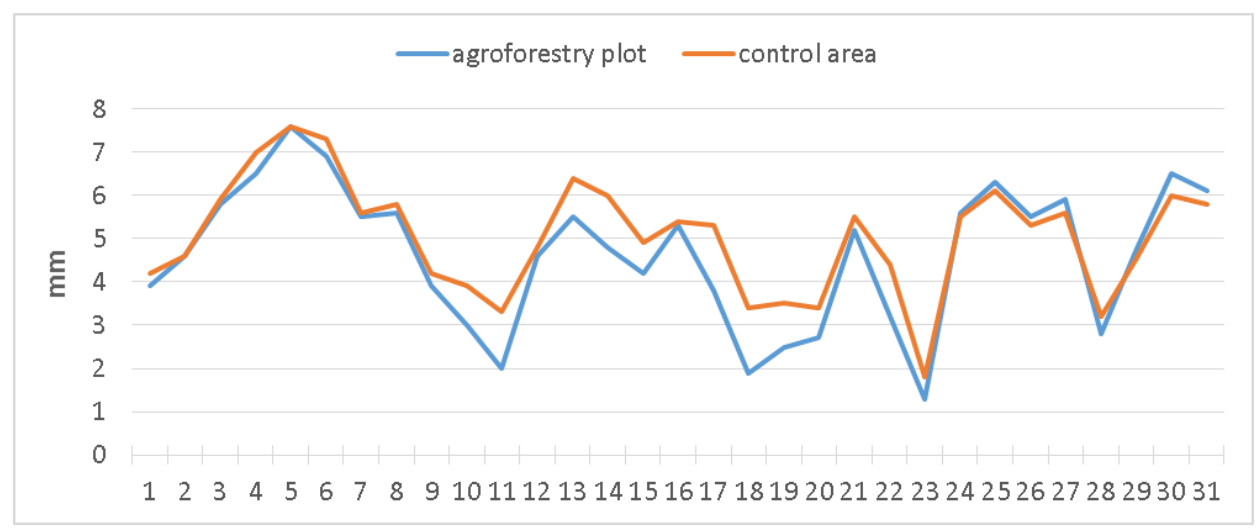

The vegetation period begins when the plants begin to breathe, which ensured a higher water vapor content again in April 2019. At the same time, the evaporation in the control area was higher than in winter, because the daily exposure to radiation increased, while the shade effect was still greater in the agroforestry plot. On the other hand, the air movement was also intensifying, because spring is the windiest period in Hungary. 


\section{Effects of the forest belt on wind speed}

Wind conditions were compared in the control area and agroforestry plot using wind roses, plotted from 10-minute wind speed values between April 2018 and March 2019 (Figure 5). The typical wind direction on both areas was southwest $\left(180^{\circ}\right.$ to $\left.270^{\circ}\right)$. The relative frequency of wind speed from $260^{\circ}$ to $90^{\circ}$ (from western, northern and eastern directions) was 10-15\% with typical wind speed under $10 \mathrm{~m} / \mathrm{s}$ in both areas. The differences could be detected between $180^{\circ}$ and $210^{\circ}$ (southern, southwestern directions). On the control area the wind speed was significantly higher, which occasionally exceeded $15 \mathrm{~m} / \mathrm{s}$ (stormy wind).

\section{Figure 5}

\section{Representation of wind speed distribution in the agroforestry plot and on the control area with 10 -minute spatial resolution}
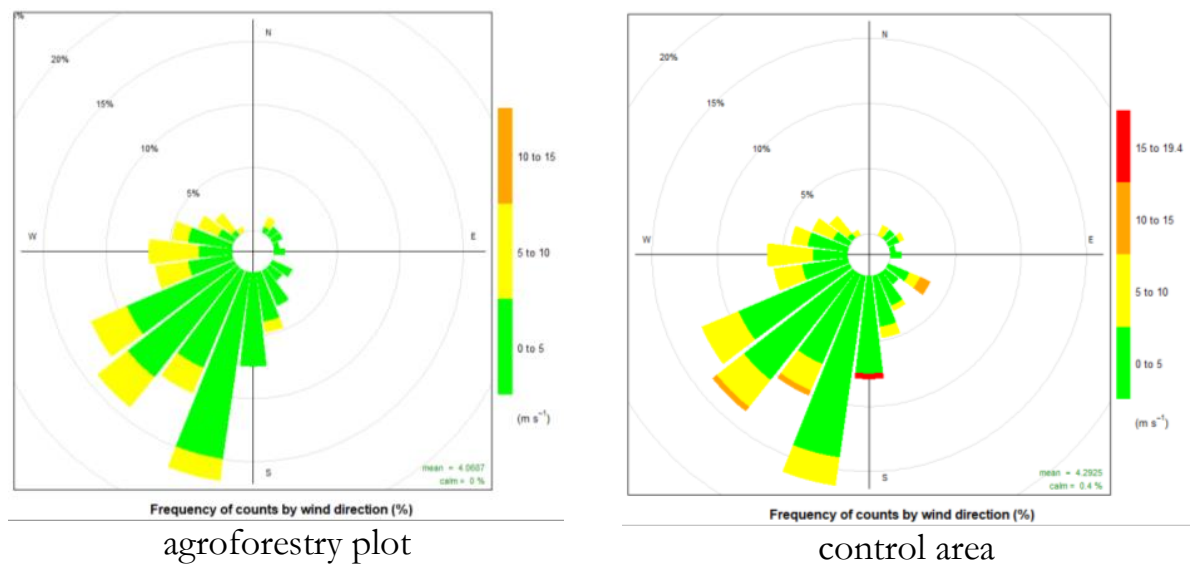

Optimal stoma operation requires some air movement up to $1.7 \mathrm{~m} / \mathrm{s}$. Stronger winds enhance the transpiration, and as a consequence they decrease the turgor pressure and so stomas may close in a hydroactive way. The relative frequency of wind speed below $1.7 \mathrm{~m} / \mathrm{s}$ was calculated. It was found that wind speed under this threshold occurred four times more often than in the control area (Table 1). This means that the agroforestry plot proved to be more favourable for transpiration due to the wind shading effect of the forest belt.

\section{Table 1}

Relative frequency of wind speeds below $1.7 \mathrm{~m} / \mathrm{s}$

\begin{tabular}{|l|c|c|}
\hline & Agroforestry plot & Control area \\
\hline July 2018 & $77 \%$ & $15,2 \%$ \\
\hline October 2018 & $76,5 \%$ & $33,5 \%$ \\
\hline April 2019 & $41,6 \%$ & $8,8 \%$ \\
\hline July 2019 & $73,7 \%$ & $17,2 \%$ \\
\hline
\end{tabular}




\section{Analysis of soil moisture}

The top layer of soil is in direct connection with the atmosphere, so the external influences on the area have the greatest impact on this layer. As a result, the greatest fluctuation in soil moisture can be measured in this layer. Even the smallest amount of rainfall temporarily rose the soil moisture value, which started to decrease rapidly due to absorption or evaporation. In the agroforestry plot, the upper $5 \mathrm{~cm}$ soil layer was drier than in the control area. This can be explained by the extraction effect of the tree roots, which was already present in the soil slowing down the vertical infiltration. On the contrary, the changes of soil moisture content on the control area was more variable and rapid owing to the higher wind speeds, and consequently, to the more active evaporation. At a depth of $35 \mathrm{~cm}$, large fluctuations in soil moisture content disappeared in the agroforestry plot (Figure 6). During the drought between June and August in 2018, the soil moisture in the agroforestry plot was higher due to reduced air movement and hence less evaporation. Rainfall in August temporarily increased the amount of soil moisture on the control area, but the effect was shortlived.

\section{Figure 5}

\section{Soil moisture between $5 \mathrm{~cm}$ and $85 \mathrm{~cm}$ by $1 \mathrm{~cm}$ steps calculated with linear interpolation in the forest belt with north-south exposure, in the forest belt with east-west exposure and in the control area}
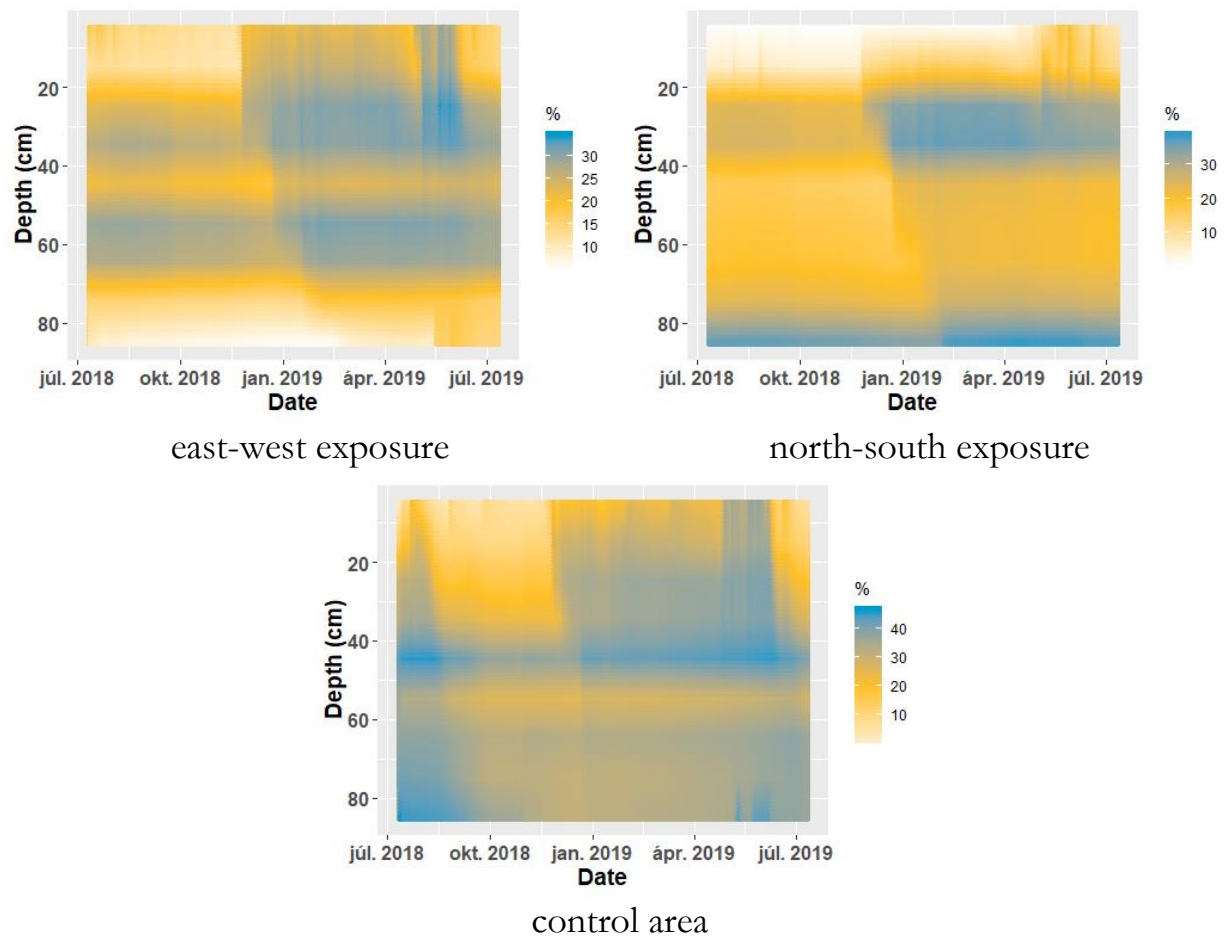


\section{Figure6}

\section{Soil moisture at $35 \mathrm{~cm}$ depth in the agroforestry plot and on the control area between March and August 2019}

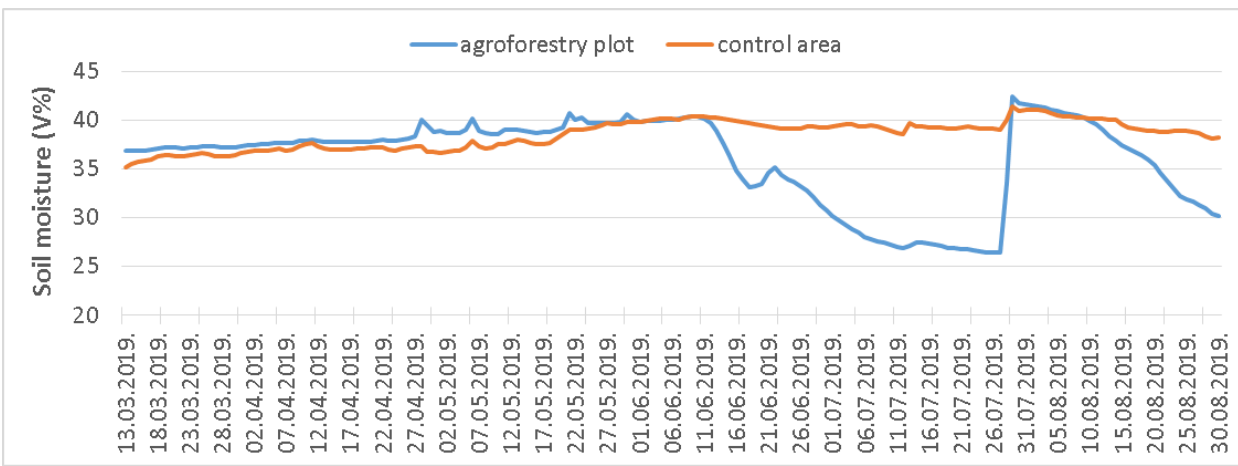

\section{CONCLUSIONS}

The daily heat fluctuation in the agroforestry plot was higher compared to the control area, which can be explained by the lower wind speed in the enclosed area. The temperature rose more sharply in the morning and the cooling rate was faster in the afternoon as well compared to the control area. The daily humidity in the agroforestry plot was also higher than in the control area, which was related to the significant decrease of the wind speed and the greater daily fluctuation of temperature.

The daily potential evapotranspiration was typically lower in the agroforestry plot. The conditions in the agroforestry system are more favourable to the functioning of the stomas, which can enhance the photosynthesis of the crop. This can be explained by the fact that due to the wind shade effect of the forest belt, there were fewer and less wind gusts. Based on soil moisture measurements, it can be concluded that in summer, the control area values indicated a greater degree of soil drought than the agroforestry plot. In the winter season, the parameters measured in the two areas were in balance, and in spring, significant differences began to appear again after the beginning of the vegetation period.

As a conclusion, we were able to prove some positive effects of the microclimatic and soil moisture factors influenced by the agroforestry systems.

\section{ACKNOWLEDGEMENTS}

The work is supported by GINOP 2.3.4-15-2016-00005 and EFOP 3.6.2-16-201700018, "Produce together with the nature - agroforestry as a new outbreaking possibility projects.

\section{REFERENCES}

Gyuricza, Cs., Borovics, A. (2018): Agrárerdészet. Budapest: Mezőgazda Kiadó, ISBN 9786155748059, 259 p. 
Keserű, Zs. (2014): Agroerdészet Magyarországon. In: Erdészeti Lapok, 169. 2. 4950. p.

Keserű, Zs., Honfy, V., Kiss, T., Kovács, Cs., Rásó, J. (2015): Agro-erdészeti rendszerek hazai alkalmazásának jelentősége. In: Alföldi Erdőkért Egyesület Kutatói nap Kiadvány, 2015. 29-32. p.

Nair, P.K.R., Garrity, D. (Eds.). (2012): Agroforestry - The Future of Global Land Use. In: Advances in Agroforestry. 9. 21-27. p. doi:10.1007/978-94-007-4676-3

R Core Team (2017): R: A language and environment for statistical computing. R Foundation for Statistical Computing, Vienna, Austria. [online] <URL https://www.R-project.org/>

Vityi, A., Marosvölgyi, B. (2014): Hagyományos és új agroerdészeti technológiák lehetséges szerepe az Alföld klímaérzékenységének mérséklésében. In: Alföldi Erdőkért Egyesület Kutatói nap Kiadvány, 2014. 37-40. p.

Corresponding author:

\section{Katalin SOMFALVI-TóTH}

Kaposvár University

Faculty of Agricultural and Environmental Sciences

H-7400 Kaposvar Guba S.u. 40.

tel: +36 82 505-800

e-mail: somfalvi-toth.katalin@ke.hu 